\title{
PENYUSUNAN INDEKS KESADARAN POLITIK DI KALANGAN MAHASISWA
}

Studi Pada Politeknik Statistika STIS

\author{
(The Construction of Political Awareness Index Among Students: Study at \\ Polytechnic of Statistics STIS)
}

\author{
Nabilla Fathasya Arom ${ }^{1}$, Risni Julaeni Yuhan² \\ Politeknik Statistika STIS ${ }^{1,2}$ \\ Jl. Otto Iskandardinata No. 64C, Jatinegara, Jakarta Timur, 13330 \\ E-mail: 16.9317@stis.ac.id
}

\begin{abstract}
ABSTRAK
Sebagai agen perubahan, mahasiswa dituntut untuk memiliki kesadaran politik yang baik. Dengan kesadaran politik yang baik maka mahasiswa memiliki kesadaran akan posisinya dalam sebuah tatanan kehidupan bernegara yang lebih lanjut memperkuat sistem demokrasi negara tersebut. Selama ini kesadaran politik diukur melalui tingkat partisipasi politik berupa voters turnout dan indeks demokrasi Indonesia (IDI) khusus aspek hak-hak politik. Pengukuran tersebut merupakan pengukuran tidak langsung yang terkadang menghasilkan tingkat kesadaran politik berbeda tergantung jenis partisipasi politik yang dipilih peneliti. Oleh karena itu diperlukan suatu indeks khusus untuk mengukur tingkat kesadaran politik seseorang. Karenanya melalui studi di Politeknik Statistika STIS penelitian ini bertujuan mendeskripsikan variabel yang mempengaruhi tingkat kesadaran politik seseorang dan menjelaskan gambaran umum tingkat kesadaran politik mahasiswa Politeknik Statistika STIS menggunakan indeks kesadaran politik (IKP). Pengukuran IKP menggunakan kuesioner yang terdiri 36 item pertanyaan yang mencakup dimensi kognitif, afektif, dan psikomotor. Data dikumpulkan menggunakan unit analisis sebanyak 140 sampel mahasiswa Politeknik Statistika STIS yang diiambil menggunakan metode Stratified Circular Systematic Sampling. Hasil analisis menemukan bahwa tingkat kesadaran politik mahasiswa Politeknik Statistika STIS tergolong sedang atau cukup baik dengan masing-masing dimensi yaitu kognitif, afektif, dan psikomotor secara berurutan termasuk dalam kategori tinggi, rendah, dan tinggi.
\end{abstract}

Kata kunci: kesadaran politik, mahasiswa, penyusunan indeks, analisis faktor konfirmatori

\section{ABSTRACT}

As agents of change, students are required to have good political awareness. With good political awareness, students have an awareness of their position in an order of state life which further strengthens the country's democratic system. So far, political awareness is measured through the level of political participation in the form of voters turnout and the Indonesian democracy index (IDI) specifically for aspects of political rights. This measurement is an indirect measurement that sometimes results in different levels of political awareness depending on the type of political participation chosen by the researcher. Therefore we need a special index to measure a person's level of political awareness. Therefore, through a study at the Polytechnic of Statistics STIS, this research aims to describe the variables that affect the level of one's political awareness and to explain the general picture of the level of political awareness using the political awareness index (IKP). The measurement of IKP uses a questionnaire consisting of 36 question items covering cognitive, affective, and psychomotor dimensions. The data were collected using the unit of analysis as many as 140 samples of Polytechnic of Statistics STIS students who were taken using the Stratified Circular Systematic Sampling method. The results of the analysis found that the level of political awareness of the Polytechnic of Statistics STIS students was moderate or good enough with each dimension, namely cognitive, affective, and psychomotor, which were in the high, low, and high categories respectively.

Keywords: political awareness, students, construct an index, confirmatory factor analysis

\section{PENDAHULUAN}

Setelah Indonesia merdeka pada tahun 1945, pergolakan politik di Indonesia terus mengalami pergerakan secara dinamis yang merubah gaya berpolitik setiap warga Negara sehingga setiap orang lebih berani mengeluarkan pendapatnya. Namun aksi menyampaikan pendapat 
(demonstrasi) yang berujung ricuh dan tanpa memahami konteks yang disuarakan merupakan wujud ketidaksadaran politik yang berakibat melemahkan demokrasi suatu negara. Ketidaksadaran politik merupakan lawan dari kesadaran politik. Kesadaran politik adalah kondisi memiliki pengetahuan akan fenomena, lembaga, dan konsep penting terkait sistem politik (Lal, 2018).

Pada tingkat nasional, tingkat kesadaran politik dapat didekati melalui partisipasi politik yaitu voters turnout pemilu dan indeks demokrasi Indonesia (IDI) khusus untuk aspek hak-hak politik (Yuliantiana, 2016). Voters turnout merupakan salah satu bentuk partisipasi politik dalam pemilu yang dihitung melalui persentase orang yang menggunakan hak pilihnya dibandingkan jumlah seluruh warga negara yang berhak memilih (Budiarjo, 2008). Begitupula dengan IDI khusus untuk aspek hak-hak politik yang dapat menggambarkan partisipasi politik seseorang karena memasukkan bentuk partisipasi politik dalam variabel penyusunnya yaitu demonstrasi dan pengaduan masyarakat mengenai penyelenggaraan pemerintahan.

Dinamika sistem politik dan pemerintahan di tingkat nasional turut merubah pula gaya berpolitik mahasiswa di lingkungan kampus. Sebagai agent of change, mahasiswa diharapkan sadar akan politik. Hal ini terkait dengan peran mahasiswa dalam meningkatkan social control terhadap pemerintah. Penerapan social control oleh mahasiswa selama ini melalui penyampaian opini secara terbuka di depan publik (demonstrasi) dan penulisan kritik di media cetak atau elektronik. Oleh karena itu penting bagi mahasiswa untuk sadar akan politik karena mereka adalah penggerak yang aktif mengawasi dinamika perpolitikan Indonesia dan pelaku politik kedepannya (Hatta, 2017).

Dikalangan mahasiswa misalnya mahasiswa Politeknik Statistika STIS, tingkat kesadaran politik juga dapat didekati melalui tingkat partisipasi politiknya yaitu voters turnout mahasiswa dalam pemilihan umum raya (pemira) ketua senat mahasiswa (SEMA) dan keterlibatan mahasiswa dalam pengawasan kebijakan di kampus melalui pemberian saran dan opini kepada dewan perwakilan mahasiswa (DPM).

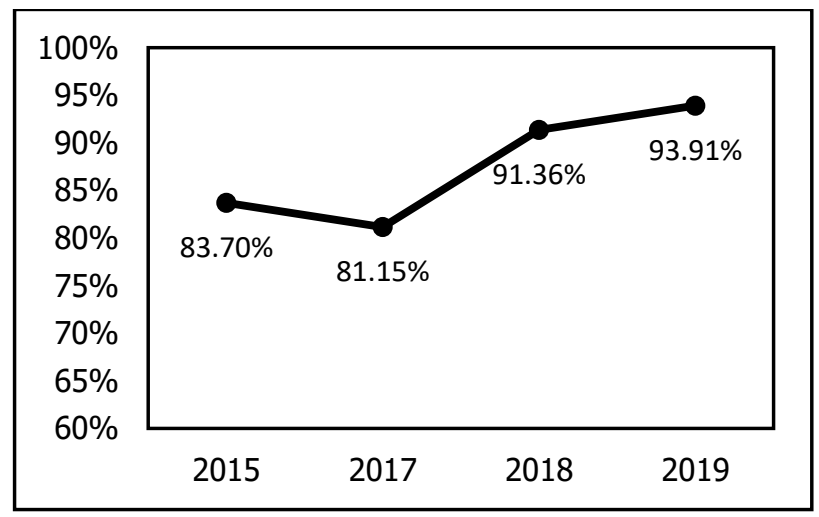

Sumber: PPDS Polstat STIS, 2019

Gambar 1. Tingkat Partisipasi Pemilihan Ketua dan Wakil Ketua SEMA

Pada Gambar 1 terlihat bahwa tingkat partisipasi mahasiswa Politeknik Statistika STIS dalam pemira selalu berada diatas delapan puluh persen dan memiliki tren yang meningkat. Artinya tingkat partisipasi politik mahasiswa Politeknik Statistika STIS cukup baik dan cenderung untuk terus mengalami peningkatan. Namun tingkat kesadaran politik mahasiswa Politeknik Statistika STIS yang didekati melalui penerapan politik dalam bentuk menghadiri kampanye pemira dan menyuarakan pendapatnya mengungkapkan kondisi yang berbeda jauh. Berdasarkan data panitia pemilihan DPM dan SEMA (PPDS) Politeknik Statistika STIS, pada kampanye calon ketua dan wakil ketua SEMA setiap tahunnya, mahasiswa yang hadir tidak mencapai sepuluh persen dari 2201 mahasiswa, dan yang hadir didominasi oleh tim sukses. Pada kegiatan lain yaitu sidang umum untuk mendengarkan laporan kerja akhir tahun dan mengusulkan program kerja baru SEMA dan DPM, mahasiswa yang hadir hanyalah anggota DPM dan SEMA saja walaupun dibuka untuk semua mahasiswa. Jumlah aspirasi yang disampaikan mahasiswa ke DPM juga sedikit yaitu berada dikisaran lima persen.

Kondisi kesadaran politik mahasiswa yang diukur menggunakan pendekatan tidak langsung seperti pada kasus di Politeknik Statistika STIS menghasilkan tingkat kesadaran politik yang 
berbeda tergantung jenis partisipasi politik yang dipilih. Selain itu, Ogunlade (2005) berpendapat bahwa pengukuran tidak langsung tidak cukup efektif dalam mengetahui tingkat kesadaran politik Indonesia karena hanya mempertimbangkan bentuk penerapannya saja tanpa menguji aspek lain yaitu tingkat pengetahuan dan pemahaman politik. Tingkat pengetahuan dan pemahaman yang dimaksud oleh Abonu ialah pengalaman dan pengetahuan yang dikumpulkan individu dari waktu ke waktu yang dapat mengembangkan respons individu tersebut dalam menyikapi isu-isu politik. Dalam penelitiannya di tahun 2013, Ogunlade memasukkan tingkat pengetahuan dan pemahaman untuk mengukur tingkat kesadaran politik siswa kelas tiga SMP di Nigeria melalui skala psikologis. Skala psikologis tersebut mencakup tiga aspek yaitu aspek kognitif, afektif, dan psikomotor.

Beberapa peneliti turut mengadopsi skala psikologis yang digunakan oleh Abonu. Seperti penelitian yang dilakukan Ahmed pada tahun 2015 di Multan, Pakistan. Ahmed meneliti kesadaran politik mahasiswa Universitas Bahaudin Zakariya fakultas ilmu sosial dan fakultas ilmu alam. Hasil penelitian menemukan bahwa kesadaran politik mahasiswa fakultas ilmu sosial Universitas Bahaudin Zakariya, Pakistan lebih tinggi dibandingkan fakultas ilmu alam. Penelitian lain yang mengadopsi kuesioner penelitian Abonu ialah penelitian yang dilakukan oleh Rojihah pada tahun 2015. Rojihah meneliti perbedaan kesadaran politik antara gender feminin dan maskulin pada mahasiswa fakultas ilmu sosial dan politik (FISIP) Universitas Brawijaya. Hasil penelitian menunjukkan bahwa tidak ada perbedaan kesadaran politik antara gender feminin dan maskulin pada mahasiswa FISIP Universitas Brawijaya.

Melihat penelitian-penelitian yang telah dilakukan sebelumnya, belum ada peneliti yang mengukur tingkat kesadaran politik menggunakan indeks komposit. Padahal dengan mengggunakan indeks komposit terdapat beberapa kelebihan, diantaranya yang pertama tingkat kesadaran politik lebih mudah untuk dibandingkan antar kelompok, kemudian dapat dilihat perkembangannya dari waktu ke waktu, serta penggunaan indeks komposit juga lebih menarik perhatian publik (OECD, 2008). Oleh karena itu pada penelitian ini digunakan indeks komposit untuk mengukur tingkat kesadaran politik mahasiswa Politeknik Statistika STIS. Indeks disusun dengan mengadopsi tiga aspek skala psikologis yang telah digunakan Ogunlade (2013) yaitu kognitif, afektif, dan psikomotor.

\section{METODE}

\section{Pengumpulan Data}

Data yang digunakan dalam penelitian ini adalah data primer. Data dikumpulkan pada tanggal 4 Juni 2020 menggunakan kuesioner yang diisi secara online oleh 140 sampel mahasiswa Politeknik Statistika STIS yang terpilih melalui metode Stratified Circular Systematic Sampling with Equal Allocation. Data primer dalam penelitian ini mencakup informasi mengenai karakteristik umum, keaktifan organisasi, dan kesadaran politik yang terbagi ke dalam tiga aspek yakni kognitif, afektif, dan psikomotor.

\section{Analisis}

Metode analisis yang digunakan dalam penelitian ini adalah analisis deskriptif. Analisis deskriptif digunakan untuk memperoleh gambaran kesadaran politik mahasiswa Politeknik Statistika STIS. Kemudian dilakukan analisis faktor konfirmatori untuk menguji kecocokan hubungan variabel pada tiap aspek penyusun indeks kesadaran politik. Analisis faktor dilakukan melalui beberapa tahap sebagai berikut.

1. Uji Bartlett (Bartlett Test of Sphericity)untuk melihat signifikansi dari korelasi antarvariabel secara keseluruhan dari suatu matriks korelasi (Hair, dkk., 2010). Hipotesis yang digunakan adalah sebagai berikut

$\mathrm{H}_{0}=$ matriks korelasi merupakan matriks identitas

$\mathrm{H}_{1}=$ matriks korelasi bukan merupakan matriks identitas

Dengan taraf uji sebesar sepuluh persen maka tolak $H_{0}$ ketika p-value $<0,1$. Sehingga dapat disimpulkan bahwa matriks korelasi bukanlah matriks identitas, artinya antar variabel terdapat korelasi yang kuat.

2. Uji Kaiser Meyer Olkin (KMO) 
Uji KMO digunakan untuk melihat kecukupan sampel agar analisis faktor bisa dilanjutkan. Perhitungan statistik uji KMO seperti pada persamaan berikut (Widarjono, 2010).

$$
\mathrm{KMO}=\frac{\left[\sum \sum_{i \neq j} r_{i j}^{2}\right]}{\left[\sum \sum_{i \neq j} r_{i j}^{2}+\sum \sum_{i \neq j} a_{i j}^{2}\right]}
$$

Keterangan:

$r_{i j}=$ koefisien korelasi sederhana antara variabel $\mathrm{i}$ dan $\mathrm{j}$

$a_{i j}=$ koefisien kokrelasi parsial antara variabel $\mathrm{i}$ dan $\mathrm{j}$

Data dinyatakan cukup untuk analisis faktor jika statistik uji KMO bernilai diatas atau sama dengan 0,6 (Sharma, 1996).

3. Estimasi matriks faktor digunakan untuk menghasilkan faktor loading seperti pada persamaan. Dalam penelitian ini metode estimasi yang digunakan adalah maximum likelihood (ML). Sebelum dilakukan estimasi, dilakukan uji asumsi normalitas menggunakan plot antara jarak mahalanobis dengan chi-square. Jika plot mendekati garis lurus maka asumsi multivariat normal terpenuhi. Setelah pengujian asumsi, maka estimasi maximum likelihood dilakukan untuk mendapatkan faktor loading dan memeriksa apakah variabel valid mengukur kesadaran politik mahasiswa Politeknik Statistik STIS. Variabel valid jika loading factor bernilai diatas 0,45 (Tabachnik dan Fidell, 2007). Jika valid maka proses perhitungan indeks dapat dilakukan. Indeks kesadaran politik (IKP) dihitung menggunakan agregasi geometrik yang dapat dituliskan sebagai berikut:

$$
\begin{aligned}
& \text { IKP }=\sqrt[3]{I_{\text {Kognitif }} x I_{\text {Afektif }} x I_{\text {Psikomotor }}} \\
& \text { dimana } \\
& I_{\text {Aspek }}=\frac{\sum_{i=1}^{j} \text { Skor } X_{i}}{\text { Skor Total Aspek }}
\end{aligned}
$$

Setelah perhitungan maka langkah selanjutnya adalah kategorisasi nilai indeks. Kategorisasi nilai indeks bertujuan untuk mempermudah proses analisis dan interpretasi. Menurut James T. LaPlant (1998) kesadaran politik dapat dibagi menjadi empat kategori yaitu rendah, sedang, tinggi, dan sangat tinggi. Indeks dibagi menurut interval sebagai berikut.

Tabel 1. Kategorisasi Nilai IKP

\begin{tabular}{ll} 
Kategori & Interval \\
\multicolumn{1}{c}{$(1)$} & \multicolumn{1}{c}{$(2)$} \\
Rendah & Indeks $\leq 0,60$ \\
Sedang & $0,60<$ Indeks $\leq 0,70$ \\
Tinggi & $0,70<$ Indeks $\leq 0,80$ \\
Sangat Tinggi & Indeks $>0,80$
\end{tabular}

\section{HASIL DAN PEMBAHASAN}

\section{Gambaran Umum Sampel Penelitian}

Mahasiswa merupakan istilah yang digunakan bagi pelajar yang melanjutkan sekolahnya ke perguruan tinggi. Dalam perjalanannya menuntut ilmu, tanpa disadari mahasiswa sering berkelompok menurut kesamaan-kesamaan yang dimiliki. Misalnya mahasiswa lebih mudah berteman dengan mahasiswa lain yang berasal dari daerah yang sama karena kesamaan bahasa dan budaya. Kesamaan-kesamaan ini disebut juga sebagai karakteristik. Dalam penelitian ini selain diambil informasi mengenai kesadaran politik individu, ditanyakan juga karakteristik yang dimiliki oleh setiap responden. Karakteristik responden merupakan informasi tambahan yang dapat digunakan untuk memperkaya data dan interpretasi penelitian. Gambaran umum karakteristik responden diterangkan dalam Tabel 2

Tabel 2. Karakteristik sampel penelitian

\section{Karakteristik Umum Kategori}

(1)

Jenis Kelamin
(2)

Laki-laki

Perempuan

Jawa

\section{Persentase}

(3)

52,14

47,86

67,86 
Daerah Asal

Mengikuti Organisasi

$$
\text { Luar Jawa }
$$

Ya

Tidak
32,14

25

75

Secara keseluruhan, jumlah mahasiswa laki-laki dan perempuan yang menjadi sampel dalam penelitian ini tidak berbeda jauh. Namun demikian, mahasiswa laki-laki memiliki persentase yang lebih tinggi dibandingkan mahasiswa perempuan. Kemudian dari daerah asalnya terlihat bahwa sebagian besar sampel berasal dari pulau Jawa dan hanya 32,14 persen sampel yang berasal dari luar Jawa. Karakteristik terakhir yaitu keaktifan organisasi, dapat dilihat dari tabel 9 bahwa sebagian besar sampel mahasiswa Politeknik Statistika STIS tidak mengikuti organisasi. Sedikitnya jumlah mahasiswa yang mengikuti organisasi bisa disebabkan oleh beberapa faktor, pertama adalah kuota yang terbatas, misalnya pengurus SEMA yang hanya berjumlah 46 mahasiswa sedangkan yang mendaftar tiap tahunnya berkisar 100 lebih mahasiswa, artinya tidak semua mahasiswa yang ingin mengikuti organisasi memiliki kesempatan untuk dipilih, kedua keanggotaan yang tertutup misalnya DPM yang merupakan organisasi yang mewadahi seluruh ketua kelas di Politeknik Statistika STIS sehingga mahasiswa selain ketua kelas tidak dimungkinkan menjadi anggota DPM, ketiga adalah memecah fokus mahasiswa, mendapat nilai yang baik merupakan keinginan banyak mahasiswa Politeknik Statistika STIS karena dengan begitu maka prospek studi kedepannya seperti memperoleh beasiswa menjadi lebih bagus dan jika mendapat IPK tertinggi maka bisa memilih lokasi penempatan yang diinginkan, karenanya banyak mahasiswa yang tidak ingin mengikuti organisasi karena dapat memecah fokus dan susah membagi waktu yang berdampak pada perkuliahan.

\section{Penyusunan Indeks Kesadaran Politik}

Indeks kesadaran politik merupakan alat yang digunakan untuk mengukur kesadaran politik. Dalam penelitian ini indeks digunakan untuk mengukur tingkat kesadaran politik perseorangan. Indeks kesadaran politik memuat tiga dimensi yaitu kognitif, afektif, dan psikomotor. Dimensi kognitif mencakup variabel institusi dengan indikator pemahaman akan peran lembaga politik yaitu eksekutif, legislatif, dan yudikatif, hak warga negara dengan indikator pengetahuan atas hak dan kewajiban warga negara, dan lingkungan sosial dengan indikator ketertarikan terhadap politik dan keterpaparan politik. Dimensi afektif mencakup variabel hak warga negara dengan indikator sikap saat mendapatkan hak dan menjalankan kewajiban sebagai warga negara, kepemimpinan dengan indikator loyalitas pada negara, serta budaya dan identitas dengan indikator pengaruh budaya dan identitas pada sikap politik. Dimensi psikomotor mencakup variabel hak warga negara dengan indikator kemampuan saat menjalankan hak dan kewajibannya sebagai warga negara, perubahan sosial dengan indikator kemampuan dalam mengatasi perubahan situasi di lingkungan sekitar yang berkaitan dengan politik, dan integrasi nasional dengan indikator kemampuan mengatasi masalah kesatuan dan perpecahan baik di level terendah yaitu lingkungan sekitar hingga level tertinggi pada batas negara.

Sebelum perhitungan indeks kesadaran politik dilakukan, diperlukan analisis multivariat untuk melihat kecocokan indikator sehingga mendapatkan indikator yang benar-benar berkontribusi pada fenomenan yang diteliti. Metode analisis yang dipilih yakni analisis faktor konfirmatori. Dalam proses analisis faktor konfirmatori dilakukan beberapa pengujian yakni uji Bartlett, uji KMO, uji normalitas, dan terakhir dengan mengestimasi loading factor.

Pertama, uji Bartlett diperlukan untuk melihat apakah matriks korelasi adalah matriks identitas atau bukan, jika hasil pengujian signifikan artinya matriks korelasi bukanlah matriks identitas (Hair et al., 2010). Berdasarkan Bartlett's test of sphericity (Tabel 3), p-value kurang dari taraf uji yakni 0,1 sehingga dapat disimpulkan bahwa hasilnya signifikan atau matriks korelasinya bukanlah matriks identitas.

Tabel 3. Hasil uji Bartlett dan KMO

\section{Pengujian Asumsi}

(1)

Bartlett's Test of Sphericity

KMO

\section{Statistik Uji}

(2)

176,329

0,710

\section{p-value}

(2)

0,000
Keputusan

(4) 
Kedua, uji KMO dilakukan untuk melihat kelayakan data yang digunakan, dimana data dinyatakan cukup untuk analisis faktor jika hasil uji KMO minimal 0,6 (Sharma, 1996). Dari Tabel 3 diketahui bahwa hasil uji KMO sebesar 0,71 menandakan bahwa data telah cukup untuk analisis faktor.

Selanjutnya adalah mengestimasi loading factor yang sebelumnya harus memenuhi asumsi multivariate normal terlebih dahulu karena menggunakan metode estimasi maximum likelihood.

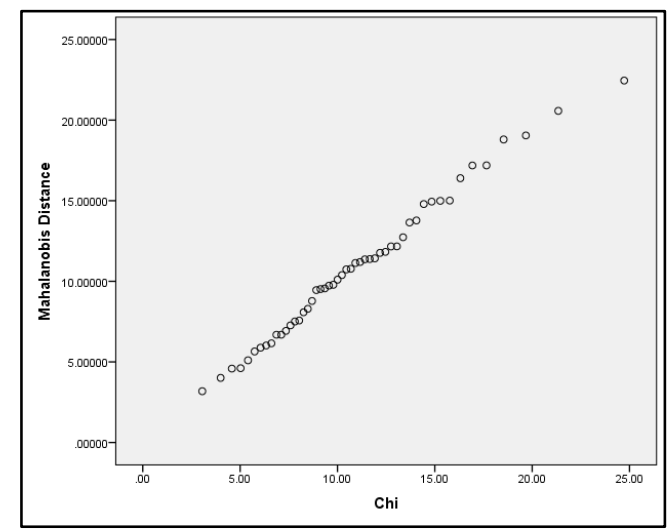

Gambar 2. Plot uji normalitas

Pengujian asumsi multivariate normal dilakukan dengan memeriksa pola data pada plot antara chi-square dengan jarak mahalanobis. Jika pola data mendekati garis lurus maka asumsi multivariate normal terpenuhi. Pada Gambar 2 ditunjukkan bahwa pola data mendekati garis lurus maka dari itu proses estimasi loading factor dapat dilanjutkan.

Tabel 4. Loading factor pada tiap variabel Variabel Loading Factor

$\begin{array}{ll}(1) & (2) \\ X_{1} & 2,88 \\ X_{2} & 0,97 \\ X_{3} & 2,30 \\ X_{4} & 0,58 \\ X_{5} & 1,80 \\ X_{6} & 1,50 \\ X_{7} & 0,68 \\ X_{8} & 0,63 \\ X_{9} & 1,00\end{array}$

Sumber: Data diolah

Comrey dan Lee (1992) dalam Tabachnik dan Fidell (2007) mensyaratkan loading factor harus berada diatas 0,45 untuk mempertahankan variabel dalam analisis faktor. Pada Tabel 4, dapat dilihat bahwa semua variabel memiliki loading factor diatas 0,45 artinya setiap variabel terbukti memiliki korelasi yang kuat dengan ketiga dimensi penyusun indeks kesadaran politik sehingga variabel dinyatakn valid untuk mengukur kesadaran politik. Setelah dilakukan perhitungan indeks kesadaran politik pada tiap sampel penelitian, data dikelompokkan menjadi beberapa (Tabel 1). Hal ini dilakukan untuk memudahkan interpretasi.

\section{Indeks Kesadaran Politik Mahasiswa Politeknik Statistika STIS}

Berdasarkan perhitungan yang telah dilakukan diperoleh bahwa IKP terkecil mahasiswa Politeknik Statistika STIS yaitu 0,433 dan IKP terbesar yaitu 0,885. Setelah menggunakan penimbang, didapatkan estimasi rata-rata IKP mahasiswa Politeknik Statistika STIS sebesar 0,656 yang berarti tingkat kesadaran politik mahasiswa Politeknik Statistika STIS termasuk dalam kategori sedang atau cukup baik. Walaupun tidak termasuk kategori rendah (kritis) namun sebagai kalangan terdidik yang diperlukan dalam mengawal dinamika perpolitikan Indonesia, mahasiswa dituntut untuk memiliki kesadaran politik yang tinggi (Hatta, 2017). Oleh karena itu kesadaran 
politik mahasiswa Politeknik Statistika STIS perlu ditingkatkan. Peningkatan bisa dilakukan dengan memulai dari mengetahui dimensi mana yang memiliki nilai indeks terkecil.

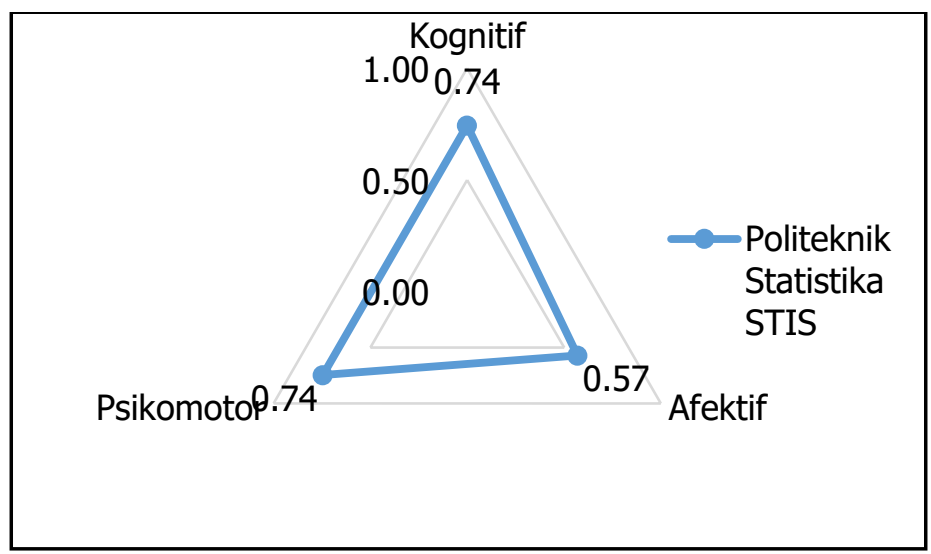

Gambar 3. Diagram radar IKP mahasiswa Politeknik Statistika STIS

Dapat dilihat dari Gambar 3 bahwa dimensi dengan nilai indeks terkecil dan memerlukan peningkatan terbesar ialah dimensi afektif. Indeks afektif sebesar 0,57 termasuk dalam kategori rendah, artinya mahasiswa Politeknik Statistika STIS masih belum mahir menyikapi isu dan fenomena politik di sekelilingnya. Salah satu penyebabnya diantaranya keengganan mahasiswa Politeknik Statistika STIS untuk mengikuti kegiatan yang berkaitan dengan politik di kampus seperti mengikuti sosialisasi saat pemira dan mengikuti jalannya sidang umum DPM dan SEMA.

Berkebalikan dengan dimensi afektif, dimensi kognitif dan dan psikomotor mahasiswa Politeknik Statistika STIS termasuk dalam kategori tinggi. Secara kognitif artinya pendidikan politik yang terwujudkan dalam pengetahuan mahasiswa Politeknik Statistika STIS akan segala hal yang berkaitan dengan politik seperti sistem, lembaga, dinamika perkembangan politik, dan lain-lain sudah baik. Menurut Jones (2019) pengetahuan politik merupakan hal yang mudah dimiliki oleh setiap orang ditambah dengan perkembangan teknologi yang memudahkan pertukaran informasi secara aktual. Sehingga tidak mengherankan bagi mahasiswa Politeknik Statistika STIS memiliki indeks kognitif yang baik karena tidak terhalang oleh jaringan yang buruk dan berdomisili di Jakarta yang mana merupakan pusat pemerintahan, media dan informasi.

Secara psikomotor keterampilan mahasiswa Politeknik Statistika STIS terkait politik sudah baik. Menurut Ogunlade (2013) partisipasi politik yaitu memberikan hak pilih dalam pemilihan merupakan salah satu wujud keterampilan seseorang terkait politik yaitu dalam menjalankan hak dan kewajibannya sebagai warga negara. Pada Gambar 1 ditunjukkan bahwa tingkat partisipasi mahasiswa Politeknik Statistika STIS dalam pemilihan ketua dan wakil ketua SEMA selalu berada diatas delapan puluh persen.

Tingkat kesadaran politik pada tiap dimensi penyusun juga dapat dipecah berdasarkan variabel-variabel penyusunnya. Hal ini untuk melihat pencapaian kesadaran politik pada tiap variabel sehingga peningkatan tingkat kesadaran politik dapat secara spesifik menargetkan hal tertentu. 


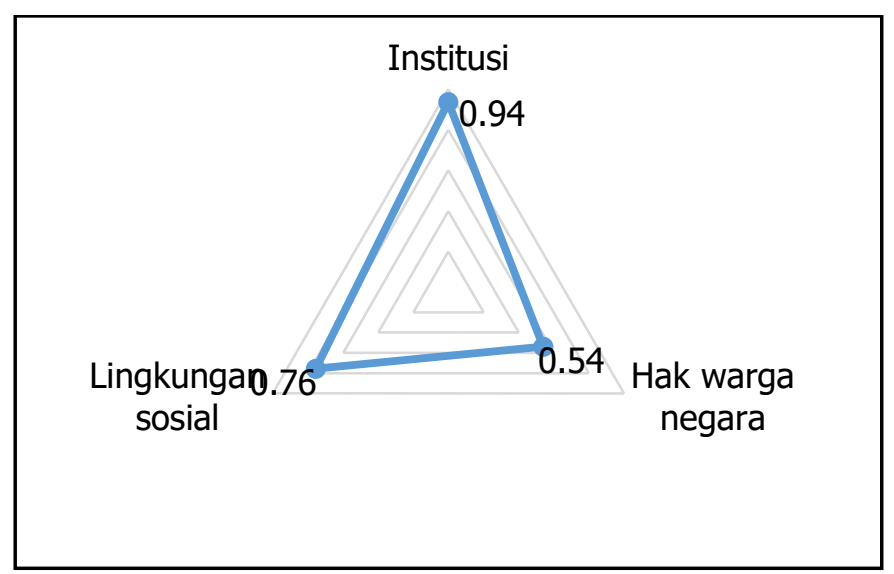

Gambar 4. Diagram radar indeks dimensi kognitif

Berdasarkan Gambar 4 diketahui bahwa dalam dimensi kognitif, variabel hak warga negara memiliki indeks terkecil. Artinya secara umum pengetahuan mahasiswa Politeknik Statistika STIS akan hak dan kewajibannya sebagai warga negara masih minim. Kemudian indeks lingkungan sosial terbilang tinggi, artinya ketertarikan dan keterpaparan mahasiswa Politeknik Statistika STIS terhadap politik sudah tinggi. Terakhir,indeks variabel institusi mendekati satu artinya pemahaman mahasiswa Politeknik Statistika STIS akan peran lembaga politik yaitu eksekutif, legislatif, dan eksekutif sudah sangat baik.

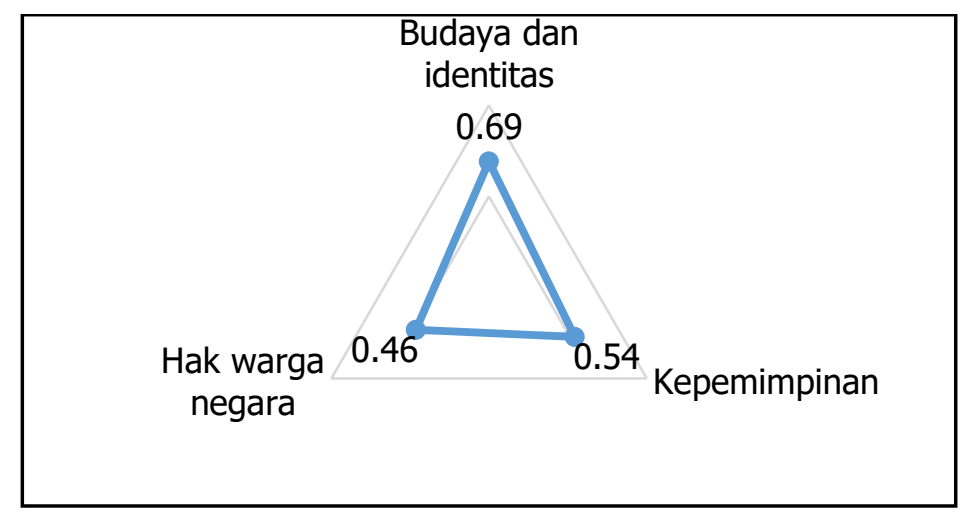

Gambar 5. Diagram radar indeks dimensi afektif

Berdasarkan Gambar 5 diketahui bahwa dalam dimensi afektif, variabel budaya dan identitas memiliki indeks terbesar dan termasuk dalam kategori sedang. Artinya sikap mahasiswa Politeknik Statistika STIS yang berkaitan dengan budaya dan identitasnya sebagai warga negara Indonesia termasuk cukup baik. Sebaliknya indeks hak warga negara dan kepemimpinan termasuk dalam kategori rendah, artinya mahasiswa Politeknik Statistika STIS masih belum mahir dalam menyikapi hal-hal yang berkaitan dengan hak dan kewajiban yang dimiliki sebagai warga negara dan belum memiliki loyalitas yang tinggi pada negara.

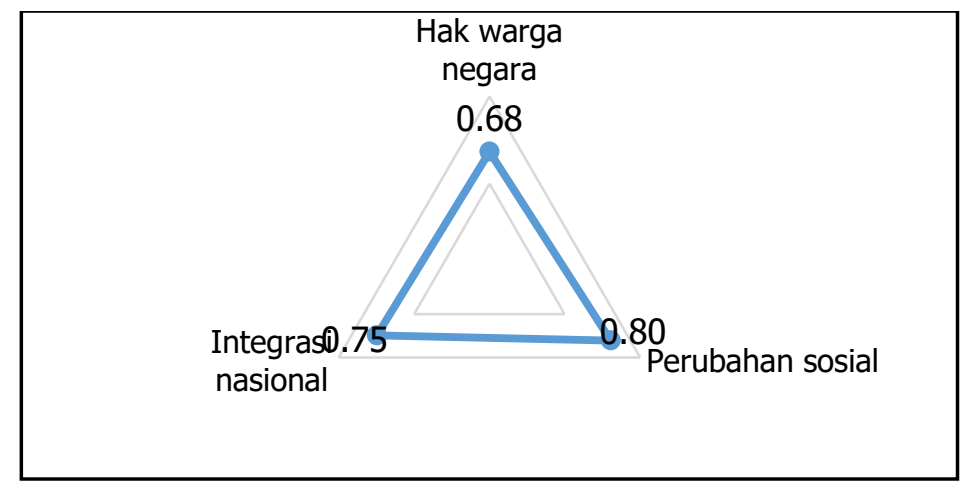

Gambar 6. Diagram radar indeks dimensi psikomotor 
Berdasarkan Gambar 6 diketahui bahwa dalam dimensi psikomotor, variabel hak warga negara memiliki indeks terkecil dan termasuk dalam kategori sedang. Artinya kemampuan mahasiswa Politeknik Statistika STIS dalam menjalankan hak \& kewajibannya sebagai warga negara sesuai aturan yang berlaku sudah cukup baik. Kemudian variabel integrasi nasional termasuk dalam kategori tinggi, artinya keterampilan mahasiswa Politeknik Statistika STIS dalam hal yang berkaitan dengan memperkuat persatuan \& mencegah perpecahan bangsa sudah baik. Terakhir yaitu variabel perubahan sosial yang termasuk kategori sangat tinggi, artinya kemampuan mahasiswa Politeknik Statistika STIS mengatasi masalah yang terjadi akibat perubahan politik di lingkungan sekitarnya sudah sangat baik.

\section{Indeks Kesadaran Politik berdasarkan Karakteristik Umum}

Tingkat kesadaran politik yang dimaksud dalam penelitian ini dibagi menjadi empat, yaitu tingkat kesadaran politik rendah, sedang, tinggi, dan sangat tinggi. Berdasarkan hasil tabulasi silang antara kesadaran politik mahasiswa dengan karakteristik umum mahasiswa Politeknik Statistika STIS, maka didapat gambaran umum tingkat kesadaran politik mahasiswa sebagai berikut.

Tabel 5. Persentase tingkat kesadaran politik mahasiswa berdasarkan karakteristik umumnya

\begin{tabular}{|c|c|c|c|c|c|c|}
\hline \multirow[b]{2}{*}{$\begin{array}{c}\text { Karakteristik } \\
\text { Umum }\end{array}$} & \multirow[b]{2}{*}{ Kategori } & \multicolumn{4}{|c|}{ Tingkat Kesadaran Politik (\%) } & \multirow[b]{2}{*}{ IKP } \\
\hline & & Rendah & Sedang & Tinggi & $\begin{array}{l}\text { Sangat } \\
\text { Tinggi }\end{array}$ & \\
\hline (1) & (2) & (3) & (4) & (5) & $(6)$ & (7) \\
\hline \multirow[b]{2}{*}{ Jenis Kelamin } & Laki-laki & 17,81 & 27,40 & 38,36 & 16,44 & 0,71 \\
\hline & Perempuan & 32,84 & 38,81 & 28,36 & 0 & 0,65 \\
\hline \multirow{4}{*}{ Tingkat } & I & 14,29 & 20 & 48,57 & 17,14 & 0,71 \\
\hline & II & 20 & 37,14 & 37,14 & 5,71 & 0,67 \\
\hline & III & 34,29 & 22,86 & 31,43 & 11,43 & 0,66 \\
\hline & IV & 31,43 & 48,57 & 14,29 & 5,71 & 0,65 \\
\hline \multirow[b]{2}{*}{ Daerah Asal } & Jawa & 31,58 & 30,53 & 29,47 & 8,42 & 0,66 \\
\hline & Luar Jawa & 11,11 & 37,78 & 42,22 & 8,89 & 0,81 \\
\hline \multirow{2}{*}{$\begin{array}{l}\text { Mengikuti } \\
\text { Organisasi }\end{array}$} & $\mathrm{Ya}$ & 10,34 & 24,14 & 37,93 & 27,59 & 0,73 \\
\hline & Tidak & 28,83 & 35,14 & 32,43 & 3,6 & 0,66 \\
\hline
\end{tabular}

Berdasarkan jenis kelamin, dapat dilihat bahwa proposi mahasiswa laki-laki yang memiliki kesadaran politik tinggi dan sangat tinggi cenderung lebih besar dibanding perempuan. Selaras dengan hal ini Zahoor Ahmed (2015) menemukan bahwa terdapat perbedaan kesadaran politik yang signifikan antara mahasiswa laki-laki dan perempuan dengan tingkat kesadaran politik mahasiswa laki-laki lebih tinggi dibanding mahasiswa perempuan.

Selanjutnya berdasarkan tingkat mahasiswa. Berdasarkan Tabel 5, dapat dilihat bahwa mahasiswa yang memiliki tingkat kesadaran politik rendah didominasi oleh mahasiswa yang telah menjalani masa pendidikan terlama yaitu mahasiswa tingkat III dan tingkat IV. Begitupula dengan mahasiswa yang memiliki tingkat kesadaran politik sedang yang didominasi oleh mahasiswa tingkat IV. Sebaliknya untuk tingkat kesadaran politik tinggi dan sangat tinggi justru didominasi oleh mahasiswa yang mengalami masa pendidikan tersingkat yaitu mahasiswa tingkat I. Hal ini dimungkinkan karena saat penerimaan mahasiswa baru pada mahasiswa tingkat I dibuka untuk jurusan ilmu sosial yang mana pada tahun ajar sebelumnya hanya dikhususkan untuk jurusan ilmu alam saja. Menurut Ahmed (2015) pelajar/mahasiswa jurusan ilmu sosial memiliki kesadaran politik yang lebih tinggi dibanding jurusan ilmu alam karena lingkungan yang mendukung untuk sarana pendidikan politik siswa.

Kemudian pengelompokan berdasarkan daerah asal, mahasiswa yang berasal dari luar Pulau Jawa cenderung memiliki kesadaran politik yang lebih tinggi dibanding yang berasal dari Pulau Jawa. Hal ini mungkin terjadi karena kondisi di luar Pulau Jawa yang cenderung lebih tidak aman dan lebih banyak konflik sehingga melatih ketanggapan psikologis dan kemampuan mengatasi masalah (Wirawan, 2013) 
Terakhir yaitu pengelompokan berdasarkan keikutsertaan dalam organisasi dalam dan luar kampus memberikan informasi bahwa mahasiswa yang bergabung dalam organisasi memiliki kesadaran politik yang lebih tinggi dibandingkan dengan mahasiwa yang tidak bergabung dengan organisasi dalam dan luar kampus. Menurut Rahman (2014) lembaga kemahasiswaan melalui program-program kemahasiswaan sebagai wahana peningkatan pengetahuan dan mental mahasiswa dalam membentuk intelektual mahasiswa dinilai sukses dalam mengawal proses pendidikan politik mahasiswa. Sehingga mahasiswa yang aktif mengikuti organisasi lebih andal dan memiliki sensitivitas yang lebih tinggi dalam mengatasi permasalahan yang berkaitan dengan politik. Sejalan dengan penelitian Muhammad Farid Salman Alfarisi RM pada tahun 2014 yang dilakukan pada mahasiswa di Yogyakarta yang menyatakan bahwa aktivis mahasiswa memiliki kesadaran politik yang lebih tinggi dibanding mahasiswa non-aktivis. Alfarisi (2014) menyatakan bahwa aktivis mahasiswa merupakan bagian dari mahasiswa sebagai kelompok elit dari masyarakat yang senantiasa memperjuangkan nilai-nilainya yang menunjukkan kepedulian kepada masyarakat dalam konteks sosial politik tertentu. Dalam memperjuangkan nilai-nilai tersebut, mahasiswa mempergunakan berbagai cara seperti diskusi dan pelatihan yang bernuansa politik, sehingga aktivis mahasiswa telah akrab dengan politik dan memiliki kesadaran politik yang baik.

\section{KESIMPULAN}

Berdasarkan hasil analisis, kesadaran politik individu dapat diukur melalui tiga dimensi yaitu dimensi kognitif (dimensi pertama) yang terdiri dari pemahaman akan peran lembaga politik, pengetahuan atas hak dan kewajiban sebagai warga negara, ketertarikan dan keterpaparan politik, dimensi afektif (dimensi kedua) yang terdiri dari sikap saat mendapatkan hak dan kewajiban warga negara, loyalitas pada negara, keterkaitan budaya dan identitas pada sikap politik, dan dimensi psikomotor (dimensi ketiga) yang terdiri dari kemampuan menjalakan hak dan kewajiban warga negara, kemampuan mengatasi perubahan situasi terkait politik, dan kemampuan mengatasi isu/masalah persatuan bangsa. Dari hasil perhitungan diketahui bahwa tingkat kesadaran politik mahasiswa Politeknik Statistika STIS tergolong sedang dengan rincian pada tiap dimensinya yaitu kognitif berkategori tinggi, afektif berkategori rendah, dan psikomotor berkategori tinggi.

Berdasarkan karakteristik umumnya, mahasiswa Politeknik Statistika STIS yang berjenis kelamin laki-laki cenderung memiliki kesadaran politik yang lebih tinggi dibanding mahasiswa perempuan, mahasiswa yang berasal dari luar pulau Jawa cenderung memiliki kesadaran politik yang lebih tinggi dibanding yang berasal dari pulau Jawa, mahasiswa yang mengikuti organisasi cenderung memiliki kesadaran politik lebih tinggi dibanding mahasiswa yang tidak mengikuti organisasi, dan tingkat kesadaran politik berdasarkan tingkat dari yang tertinggi ke terendah secara berurutan dimiliki oleh mahasiswa tingkat I, tingkat II, tingkat III, dan terakhir tingkat IV.

\section{DAFTAR PUSTAKA}

Ahmed, Z. (2015, Mei 12). Comparing the Level of Political Awareness among the Students of Social and Natural Sciences: a Case Study of Public Sector Universities in Pakistan. Pakistan Journal of Life and Social Sciences, 13(2), 64-67.

Asra, A., \& Prasetyo, A. (2015). Pengambilan Sampel dalam Penelitian Survei. Jakarta: Rajawali Pers.

Hair, J. F. (2010). Multivariate data analysis: A global perspective. Upper Saddle River, N.J: Pearson Education.

Hatta, A. F. (2017, Oktober 31). Diambil kembali dari https://kumparan.com/hanief-adrian/politikpemuda-dan-pembasisan-politik

Lal, R. (2018, January). Political Awareness among Tribes: a Comparison between two Villages of Jammu and Kashmir and Uttrakhand. International Journal for Research in Applied Science \& Engineering Technology, 6(1), 3309-3313. doi:10.22214/ijraset.2018.1459 
LaPlant, James T. (1998). "Political Learning in Adolescene: A Survey of Political Awareness and Attitudes of Middle School Students in the Heartland" [Disertasi]. Oklahoma: University of Oklahoma.

Ogunlade, D. A. (2005). The Impact Of Social Studies Education On The Political Awareness Of Secondary School Students For Citizenship Development In Nigeria. Zaria: Ahmadu Bello University.

Ogunlade, D. A. (2013, December 12). Assessment Of Political Awareness Among Students Of Social Studies In Nigerian Secondary Schools For Citizenship. International Journal of Education and Research, 1(12), 1-10.

Rojihah. (2015, Desember). Perbedaan Political Awareness Dilihat Dari Peran Gender Pemilih Pemula . JURNAL MEDIAPSI, 1(1), 59-66.

Wirawan. (2013). Konflik dan Manajemen Konflik (Konflik Perubahan dan Pengembangan). Bandung: Mandar Maju. 